\title{
Alveolar and cystic echinococcosis: towards novel chemotherapeutical treatment options
}

\author{
A. Hemphill* and J. Müller \\ Institute of Parasitology, Vetsuisse Faculty, University of Berne, Berne, \\ Switzerland
}

\begin{abstract}
Echinococcus granulosus and Echinococcus multilocularis are cestode parasites, of which the metacestode (larval) stages cause the neglected diseases cystic echinococcosis (CE) and alveolar echinococcosis (AE), respectively. The benzimidazoles albendazole and mebendazole are presently used for the chemotherapeutical treatment, alone or prior to and after surgery. However, in AE these benzimidazoles do not appear to be parasiticidal in vivo. In addition, failures in drug treatments as well as the occurrence of side-effects have been reported, leading to discontinuation of treatment or to progressive disease. Therefore, new drugs are needed to cure AE and CE. Strategies that are currently employed in order to identify novel chemotherapeutical treatment options include in vitro and in vivo testing of broad-spectrum anti-infective drugs or drugs that interfere with unlimited proliferation of cancer cells. The fact that the genome of $E$. multilocularis has recently been sequenced has opened other avenues, such as the selection of novel drugs that interfere with the parasite signalling machinery, and the application of in silico approaches by employing the Echinococcus genome information to search for suitable targets for compounds of known mode of action.
\end{abstract}

\section{Impact of Echinococcus}

Echinococcosis, caused by larval stages of Echinococcus (Cestoda, Plathelminthes), is a life-threatening disease affecting humans and livestock. Four distinct species within the genus Echinococcus have been identified, i.e. Echinococcus multilocularis, E. granulosus, E. vogeli and E. oligarthrus (Thompson, 1986). At present, seven to nine species are described (Nakao et al., 2007; Varcasia et al., 2008). All species are potentially zoonotic, two being of significant medical importance, namely E. multilocularis (small fox tapeworm) as the most pathogenic, and E. granulosus (dog tapeworm) as the most common (Rausch, 1995; McManus et al., 2003). Echinococcus multilocularis infection causes alveolar echinococcosis (AE) in intermediate hosts and humans, and is restricted to the northern hemisphere. The current incidence rate

*Fax: + 41316312477

E-mail: hemphill@ipa.unibe.ch for Germany, $0.07 / 100,000$ persons, is probably underestimated by a factor of 3-5 (Jorgensen et al., 2008). In contrast, E. granulosus, the causative agent of cystic echinococcosis (CE), occurs worldwide (Schantz et al., 1995) with hyperendemic areas in South America, North and East Africa, southern Europe and Central Asia (McManus et al., 2003). Both, AE and CE are neglected diseases, and emergence (or re-emergence), especially in developing countries, is likely (McManus et al., 2003; Eckert \& Deplazes, 2004), with an increasing economic impact due to the necessity of life-long treatments (Torgerson, 2003).

\section{Biology of Echinococcus}

The habitat of the adult worms is the intestine of their respective final host (dogs for E. granulosus, foxes, dogs and cats for E. multilocularis), where sexual reproduction and subsequent egg production take place. Faecal shedding spreads the eggs into the environment, where 
they are accidentally taken up by suitable intermediate hosts, such as small rodents for E. multilocularis, and cattle and sheep for E. granulosus. Humans represent an aberrant intermediate host that acquires disease through the accidental ingestion of eggs, with serious consequences. Eggs contain the first larval stage, the oncosphere, which actively penetrates the intestinal lining, and migrates via blood and lymphatic vessels to the target sites. Most affected organs in humans are the liver for E. multilocularis, and the liver, lung and other sites in the case of E. granulosus. There, these oncospheres develop into metacestodes representing the second larval stage and the disease-causing stage. Within these metacestodes, protoscolex development takes place in natural intermediate hosts. If an infected intermediate host is ingested by a suitable definitive host, the life cycle is concluded. Protoscolex development in humans has only rarely been described (Eckert et al., 1983).

Metacestodes are fluid-filled vesicles that can be separated into two distinct structural entities, namely a cellular and an acellular compartment (see fig. 1). The outer acellular surface of the metacestode is formed by the laminated layer, a carbohydrate-rich structure synthesized by the parasite, which, in terms of thickness, is much more prominent in E. granulosus metacestodes (Gottstein \& Hemphill, 1997). In addition, E. granulosus metacestodes are surrounded by a very prominent hostderived fibrous capsule, the adventitial layer composed of
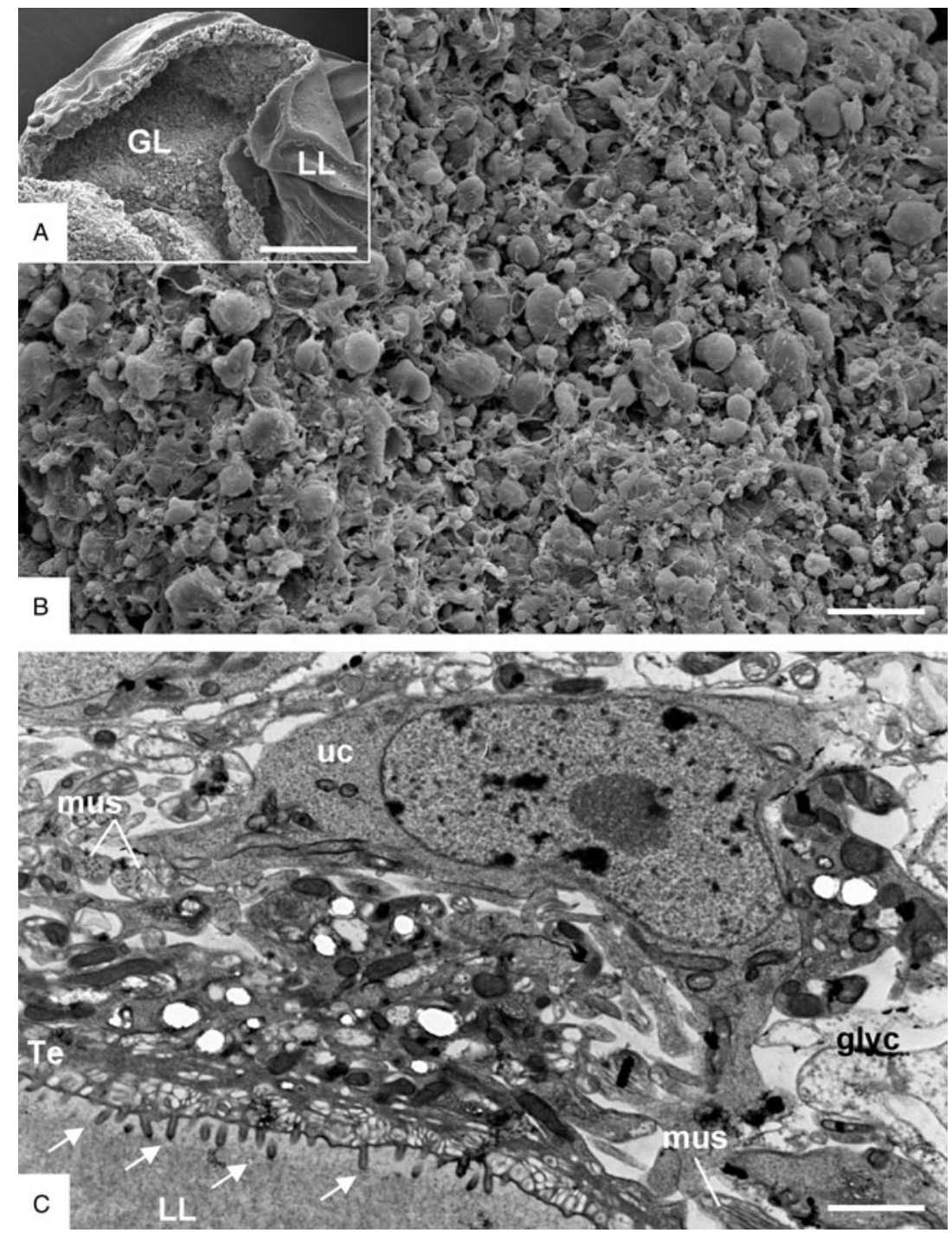

Fig. 1. Morphology and ultrastructure of Echinococcus metacestodes. (A) A lower magnification view of an opened metacestode exposing the inner germinal layer (GL)-associated tissue, and the acellular laminated layer representing the parasite surface (LL). Scale bar $=2.5 \mathrm{~mm}$. (B) A higher magnification of the GL. Scale bar $=380 \mu \mathrm{m}$. (C) TEM through the metacestode wall. The parasite tissue is composed of the tegument (Te), a syncytial layer adjacent to the LL, with numerous microtriches (arrows) protruding into the LL. The germinal layer is composed of different cell types such as connective tissue cells, muscle cells (mus), glycogen storage cells (glyc), and undifferentiated cells with a large nucleus and nucleolus (uc). Scale bar $=2.5 \mu \mathrm{m}$. 
host connective tissue. The laminated layer plays a crucial role in the survival strategy of the parasite by modulating immunological and physiological reactions on the part of the host (Gottstein et al., 2002; reviewed in Siles-Lucas \& Hemphill, 2002; Walker et al., 2004a; Gottstein et al., 2006). The actual larval tissue is formed by the germinal layer, its distal part, the tegument, being directly associated with the inner surface of the laminated layer. The tegument is characterized by microvilli-like extensions termed microtriches, which protrude well into the matrix of the laminated layer, thus increasing the resorbing surface of the parasite. In addition, the germinal layer contains highly differentiated cell types, including connective tissue, muscle cells and glycogen storage cells, as well as many undifferentiated cells (Eckert et al., 1983).

Typically, the fully mature E. granulosus metacestode (i.e. hydatid cyst) is a single-chambered or septated, but unilocular, cyst that shows expansive growth and causes thereby compression of neighbouring tissue, resulting in organ dysfunction and disease (Kern, 2003, 2006). In E. multilocularis infection, the metacestode represents a multi-vesicular structure that reproduces asexually, by exogenous formation and budding of daughter vesicles, which resembles progressive tumour-like growth (Ohbayashi et al., 1971; Ali-Khan et al., 1983). This leads to the formation of a large and heterogeneous parasitic mass consisting of mostly peripheral actively proliferating sites and, in many cases, centrally located necrotic tissue. Metastasis formation may occur in other organs due to release of germinal layer cells into the blood or lymph system (Ali-Khan et al., 1983; Eckert et al., 1983; Mehlhorn et al., 1983). Spontaneous cure of AE leading to calcified lesions is possible, but it is not known how commonly this occurs (reviewed in Gottstein \& Hemphill, 1997; Vuitton et al., 2006). In fact, mass screenings in endemic areas have shown that the number of established AE infections in humans is far lower than the number of humans exposed to the eggs of the parasite and therefore sero-positive (Rausch et al., 1987; Bresson-Hadni et al., 1994; Bartholomot et al., 2002). Thus, innate or acquired immunity is able to control the parasite after infection. This opens the door for the development of appropriate immunotherapeutical tools.

\section{Current therapies}

Traditionally, treatment of echinococcosis relies on surgery and/or chemotherapy, depending on different factors such as metacestode size and location, viability status, the interaction between the expanding parasite and the adjacent host tissue, bacterial and fungal infection, and potential complications related to cyst rupture and spillage of protoscoleces (Kern, 2003, 2006).

In $C E$, radical resection of the cyst mass represents the traditional treatment strategy and is, in many instances, accompanied by chemotherapy. Protoscolicidal substances are often applied since there is a risk of spilling of cyst fluid containing protoscoleces, which would be responsible for metastasis formation (Stey \& Jost, 1993; Pawlowski, 1997; Kern, 2003, 2006). PAIR (puncture, aspiration, injection, re-aspiration) is a technique introduced in the mid-eighties. It includes percutaneous puncture of the cysts under ultrasonic guidance, aspiration of substantial amounts of cyst fluid, injection of protoscolicidal substance (e.g. 95\% ethanol), and re-aspiration of the fluid cyst content after $15-20 \mathrm{~min}$. PAIR has been used in several hundred patients. Nevertheless, the efficacy and potential risks have not been fully evaluated, and more long-term studies are needed (Morris \& Richards, 1992; Brunetti et al., 2004; Eckert \& Deplazes, 2004).

For inoperable cases, chemotherapy with the benzimidazoles albendazole (ABZ), a broad-spectrum anthihelminthic, and mebendazole (MBZ) and the heterocyclic pyrazinoisoquinoline derivative praziquantel (PZQ) remains the only option. Pawlowski et al. (2001) have evaluated over 2000 well-documented inoperable cases of CE treated with benzimidazoles. When evaluated up to 12 months after initiation of chemotherapy, $30 \%$ of patients showed cyst disappearance, $50-70 \%$ exhibited cyst degeneration indicating improvement, and in $20-30 \%$ of patients E. granulosus metacestodes did not respond to chemotherapy (Pawlowski et al., 2001). PZQ was proposed to be used alongside with benzimidazoles in CE-patients. PZQ exhibited a high efficacy against protoscoleces and metacestodes in animal experiments (Urrea-Paris et al., 1999, 2001), and the combined treatment with ABZ and PZQ given during the month prior to surgery increased the number of human patients with non-viable protoscoleces, as compared to therapy with ABZ alone (Cobo et al., 1998).

For the treatment of AE, surgery is always accompanied by chemotherapy using benzimidazoles, which should last for at least 2 years post-surgery, and monitoring of patients should be continued for 10 years (Pawlowski et al., 2001). Inoperable AE cases must undergo long-term chemotherapy, often life-long, which is based on ABZ and/or MBZ (Reuter et al., 2000, 2004). Extensive animal experimentation and observations in human patients sufferering from AE have demonstrated that ABZ and MBZ exhibit a parasitostatic rather than a parasitocidal effect (El-On, 2002; Reuter et al., 2004). Therefore, recurrence rates after interruption of therapy are high. Nevertheless, clinical studies have shown that chemotherapy has significantly increased the 10-year survival rate of inoperable or non-radically operated AE patients from $6-25 \%$ to $80-83 \%$ (Ammann \& Eckert, 1995; Eckert \& Deplazes, 2004).

Adverse reactions against benzimidazoles under long-term chemotherapy include elevation of transaminases, proteinuria, loss of hair, gastrointestinal disturbances, neurological symptoms (vertigo/dizziness), leucopenia, headache, abnormal liver biopsy, abdominal pain, fever, urticaria, thrombocytopenia, allergic shock (due to cyst collapse and liberation of E. granulosus cyst fluid) and bone marrow toxicity. A study comprised of 3282 echinococcosis patients treated with ABZ showed that most side-effects were associated with the gastrointestinal tract but no fatal cases involving ABZ therapy were described. In $3.8 \%$ of these cases, permanent discontinuation of treatment had to be undertaken (reviewed by Pawlowski, 1997; Kern, 2003). As suggested by animal experimentation, MBZ and ABZ may induce embryotoxic or teratogenic effects, and it is recommended that these drugs are not used for the 
treatment of pregnant women (Horton, 1989, 1997). Constant monitoring of drug serum levels is suggested in order to avoid toxic reactions.

Taken together, besides benzimidazoles, novel drugs are required.

\section{Methods for in vitro and in vivo evaluation of anti- echinococcal drugs}

Both in vitro and in vivo laboratory models have been used for drug evaluation (reviewed in Siles-Lucas \& Hemphill, 2002). Historically, the primary assessment of anti-echinococcal drug candidates has often been performed in mice or gerbils by evaluating parasite mass and/or health parameters of the host. This has led to the extensive use of animal experimentation, and has often yielded inconclusive results. In vitro culture of Echinococcus metacestodes has subsequently proven to be a suitable tool for the primary assessment of drug susceptibility by counting damaged metacestodes under the light microscope, followed by ultrastructural analysis by scanning and transmission electron microscopy (see, for example, Ingold et al., 1999). A rapid test for viability is eosin exclusion (Lawton et al., 2001). Another method consists in sampling culture supernatant and measuring enzymes released from damaged metacestodes (e.g. Stettler et al., 2001). Furthermore, viability and proliferative capacity of metacestodes can be analysed by quantification of 14-3-3 gene expression (Matsumoto et al., 2006; Spicher et al., 2008a). In vitro cultures also represent an ideal model system for studies on drug uptake and respective metabolic changes imposed upon the parasite (Hemphill et al., 2002a). In vitro chemotherapy studies on CE have mostly, but not exclusively, focused on protoscoleces, since these are easily cultured. Conversely, their differentiation into metacestodes is a time-consuming process and can easily take 4-6 months (Walker et al. 2004a, b). More recently, optimized in vitro culture conditions have been developed by Brehm and co-workers (Spiliotis et al., 2004; reviewed by Brehm \& Spiliotis, 2008). These in vitro methods reduce the number of animal experiments, but do not render them completely obsolete. In order to assess long-term viability and infectivity, metacestodes treated with the best drug candidates are still injected into rodents (Hemphill et al., 2002).

\section{In vitro and in vivo studies with benzimidazoles}

Since benzimidazoles, especially ABZ, are the most relevant chemotherapeutics for the treatment of $\mathrm{AE}$ and CE to date, most preclinical in vitro and in vivo studies have been performed with these compounds, with a focus on comparing the activities of different benzimidazole derivatives, and on different formulations and modes of application. In rodents, efficacies of oral administration are dependent on the duration of treatment and the age of the parasite. Efficacy rises with prolongation of the treatment, but is distinctly lower for infections that have been persisting for extended periods of time (Wangoo et al., 1987). Increased doses produce better results, although clear parasitocidal effects are never completely achieved (Taylor et al., 1989). Moreover, phenomena related to drug resistance have been described (Morris \& Taylor, 1990). Conflicting reports exist on the most suitable mode of administration of benzimidazoles. It was postulated that parenteral administration of benzimidazoles resulted in a higher efficacy than other routes in animals experimentally infected with E. multilocularis (reviewed in Siles-Lucas \& Hemphill, 2002). Combinations of ABZ with other compounds were tested in order to obtain better treatment efficacies. For instance, synergistic effects were reported for combinations of ABZ with the dipeptide methyl ester Phe-Phe-OMe (Sarciron et al., 1997). In addition, novel formulations of benzimidazoles, either as pro-drugs (Walchshofer et al., 1990), liposome-entrapped compounds (Wen et al., 1996) or colloidal, intravenously injectable formulations (Rodrigues et al., 1995) were tested in rodents and showed enhanced efficacy at lower doses than the parental compounds. However, these studies have not really been translated into clinical applications, with one exception. Chai et al. (2004) reported on improved efficacy of ABZ emulsion compared to ABZ tablets or capsules for the treatment of liver CE. Experimental prophylactic therapy of E. granulosus protoscoleces was carried out as a model that would mimic spillage during surgery, by treating protoscoleces with PZQ (Urrea-Paris et al., 2001) or a combination of PZQ and ABZ (Casado et al., 2001) prior to injection into mice. Against E. granulosus infection in rodents, a combination of fenbendazol and netobimin (Garcia-Llanazares et al., 1997) showed synergistic effects, allowing the administration of lower drug dosage. Oxfendazole, like ABZ, is a benzimidazole, used in veterinary medicine for the control of nematode infections, and has a similar antimicrobial spectrum but a longer half-life. Experimental treatments of naturally E. granulosus-infected sheep and goats suggested that oxfendazole may be as efficacious as ABZ, but does not require daily uptake of the drug (Blanton et al., 1998; Dueger et al., 1999). Another benzimidazole derivative effective againt $E$. multilocularis metacestodes in vitro is methiazole (Reuter et al., 2006).

\section{Mode of action of benzimidazoles}

When in vitro cultures of metacestodes were treated with ABZ, microtubular ultrastructure was affected (Rubino et al., 1983; Ingold et al., 1999) suggesting that ABZ interfered with tubulin polymerization (Lacey, 1990). Molecular genetics revealed that sensitivity to benzimidazoles in evolutionary distant organisms such as fungi, nematodes, platyhelmithes and various protozoa was correlated with the presence of specific alleles of $\beta$-tubulin genes (Driscoll et al., 1989; Katiyar et al., 1994; Kwa et al., 1995; Henriquez et al., 2008), the substitution of Phe to Tyr in position 200 being sufficient for switching from benomyl sensitivity to resistance in nematodes (Kwa et al., 1995). Molecular modelling of the putative ABZ binding site in ABZ-resistant Acanthamoeba $\beta$-tubulin revealed 13 residues, four of which showed sequence variation as compared to tubulins of sensitive organisms. Resistance was conferred when, besides Phe200, Phe167 was also replaced (Henriquez et al., 2008). In E. multilocularis, cDNAs of three $\beta$-tubulin genes 
were identified, two of them having a Phe in position 200 (Brehm et al., 2000). The $\mathrm{IC}_{50}$ values of $\mathrm{ABZ}$ in organisms regarded as sensitive to $A B Z$ was between $30 \mathrm{nM}$ in the protozoon Giardia lamblia (Katiyar et al., 1994, confirmed by own observations) and more than $10 \mu \mathrm{M}$ in nematode larvae (Satou et al., 2002). Clear-cut $\mathrm{IC}_{50}$ values for $E$. multilocularis metacestodes are not found in the literature. Metacestodes treated with nearly $40 \mu \mathrm{M}$ albendazolesulphoxide (ABZSO) showed symptoms with increasing severity over time (e.g. Ingold et al., 1999) and totally disintegrated only after 21 days (Reuter et al., 2006). This indicates that cytotoxic effects of ABZ (or its metabolites) due to tubulin depolymerization may be hampered in Echinococcus by: (1) the presence of an ABZ-insensitive $\beta$-tubulin complementing the sensitive isoform; (2) rapid ABZ catabolism; (3) toxicity of ABZ catabolites rather than ABZSO itself; and/or (4) a good regenerative power due to insensitive stem cells. Sensitivity of mammalian cells (carrying the benzimidazole-resistant allele 200-Tyr) lies between an $\mathrm{IC}_{50}$ around $0.25 \mu \mathrm{M}$ in HL60 cells and $20 \mu \mathrm{M}$ in Vero cells (nocodazole, another benzimidazole, is, however, 10- to 20-fold more toxic; Katiyar et al., 1994). This suggests that ABZ may also bind with low affinity to mammalian $\beta$-tubulin, and/or the existence of another, unknown, mode of action of ABZ that may be responsible for ABZ side-effects in patients, as mentioned above. In this respect, it is noteworthy to mention that Xiao et al. (1995) found the downregulation of enzymes involved in carbohydrate metabolism upon benzimidazole treatment of rodents bearing E. granulosus metacestodes.

\section{Novel chemotherapeutical treatment options}

Novel and improved therapeutical tools are needed in order to optimize treatment of CE and AE. They should have a better selectivity, thus a much greater therapeutic window than $\mathrm{ABZ}$, and be parasitocidal rather than parasitostatic. Unfortunately, the pharmaceutical industry is not developing novel treatment options besides benzimidazoles against these neglected diseases. Therefore, novel chemotherapeutics have to be identified issuing from existing drugs by one of the following strategies: (1) in vitro testing of broad-spectrum anti-infective drugs, either in parallel with, or followed by, small animal experimentation; (2) in vitro testing of drugs inhibiting proliferation of cancer cells for their effects on the viability of Echinococcus metacestodes and protoscoleces.

Furthermore, employing the currently achieved genomic sequencing efforts, the conventional strategies (1) and (2) will be complemented by two molecular genetic and in silico approaches, namely (3) the exploitation of the similarities between the parasite and mammalian signalling machineries, with a special focus on targeting specific signalling receptors; and (4) the search for suitable molecular targets for compounds of known modes of action.

\section{(1) Chemotherapeutical activities of anti-infective drugs}

Besides benzimidazoles, promising compounds with in vitro protoscolicidal action are cetrimide (Frayha et al., 1981), and the ionophore monensin
(Rogan \& Richards, 1986), but these drugs are rather ineffective against metacestodes. The imidazothiazole levamisole, an acetylcholine agonist, and the macrolide antibioticum ivermectin, a chloride-channel activator classically used against nematode infections, were shown to exhibit in vitro activities similar to benzimidazoles (Casado et al., 1989; Martinez et al., 1999; but see also Reuter et al., 2006). In rodents infected with E. multilocularis metacestodes, mytomicin C, piperazine and quinolone derivates, alkylaminoethers, and propargylic alcohols exhibited parasitostatic effects, at either lower or comparable levels as benzimidazoles (reviewed in Siles-Lucas \& Hemphill, 2002). PZQ has been used for the treatment of $\mathrm{AE}$, but experimental data in animals have shown that the efficacy of PZQ against E. multilocularis metacestodes was not satisfactory (Marchiondo et al., 1994). Also, treatment of E. multilocularis-infected mice with alpha-difluoromethylornithine was not successful (Miyaji et al., 1993).

When E. multilocularis metacestodes were treated with the thiazolide nitazoxanide (NTZ), a broad-spectrum anthelminthic also effective against enteric bacteria, Giardia and Cryptosporidium (Hemphill et al., 2006), $0.3 \mu \mathrm{M}$ caused a total disintegration after 21 days, $3 \mu \mathrm{M}$ after 14 days and $30 \mu \mathrm{M}$ after 7 days at most (Reuter et al., 2006). NTZ was thus more efficient in vitro than ABZ (see above). Ultrastructural analysis revealed that NTZ induced significant distortion of the germinal layer in vitro (Stettler et al., 2003) and severe damage in E. granulosus protoscoleces and the germinal layer of in vitro cultured E. granulosus metacestodes (Walker et al., 2004b). In vitro studies on E. multilocularis and E. granulosus employing NTZ derivatives (see Esposito et al., 2007; Hemphill et al., 2007) showed that metacestodicidal and protoscolicidal activity of this class of drugs depends largely on the presence of the nitro-thiazole moiety (Stadelmann \& Hemphill, in preparation). Echinococcus multilocularis metacestodes treated with $32 \mu \mathrm{M}$ NTZ for 14 days were non-viable when introduced into susceptible mice for 5 months (Stettler et al., 2003). In another study, metacestodes treated with the same amount of NTZ were viable in gerbils (Reuter et al., 2006). In contrast to ABZ, in vivo studies in rodents showed little or no effects of thiazolides, most likely due to their rapid metabolism. In this respect, Stettler et al. (2004) showed that NTZ, orally applied to E. multilocularis-infected mice, either alone or in combination with ABZ, exhibited a profound antiparasitic efficacy, with the ABZ/NTZ combination yielding the most promising results. Analysis of pharmacokinetics showed that the half-life of ABZsulphoxide, a metabolite of ABZ, increased upon application of ABZ in combination with NTZ (Stettler et al., 2004). Therefore, the increased efficacy observed in mice could be a result of both the direct effects of NTZ and $A B Z$ on the parasite and the inhibition of $A B Z$ catabolism by NTZ. Combination treatment with ABZ/ NTZ at concentrations as low as 3 and $4 \mu \mathrm{M}$, respectively, for 3 weeks inhibited, however, re-growth of parasites during 8 months of drug discontinuation and, also, bioassay in gerbils did not result in viable parasite infections (Reuter et al., 2006). Thus, combined ABZ/NTZ treatment exhibited a parasitocidal effect. The mode of action and especially targets of NTZ in Echinococcus are 
unknown. In G. lamblia, a nitroreductase was identified by affinity chromatography and subsequent enzymological studies as a potential target (Müller et al., 2007b). Furthermore, recombinant protein disulphide isomerases from G. lamblia and N. caninum were inhibited by NTZ and other thiazolides (Müller et al., 2007a, 2008a).

The polyene macrolide amphotericin $\mathrm{B}$ (AMB) is an antifungal compound binding to ergosterol in the cell membrane, thus causing membrane depolarization and cell damage by oxidative stress (Blum et al., 2008). In a formulation as desoxycholate, it was shown to inhibit E. multilocularis larval growth in vitro and in human patients in vivo (Reuter et al., 2003a, b). Major drawbacks of $A M B$ are its intravenous application mode and its nephrotoxic side-effects. Moreover, AMB is only parasitostatic (Reuter et al., 2003b). Nevertheless, a few cases of progressive human $\mathrm{AE}$ have been treated with $\mathrm{AMB}$, and prolonged application of AMB over months to years appears to be feasible, as side-effects have been milder than expected (Reuter et al., 2003b). Itraconazole, an antimycotic with a similar mode of action as AMB, was also slightly effective against metacestodes, but only parasitostatic (Reuter et al., 2006).

Isoprinosine, an inosine derivative commercialized as an immunostimulant, affected viability of protoscoleces in vitro, thus not mediated by the immune system of the host (Lawton et al., 2001).

Artemisinin and artemisinin-derivatives are widely used in malaria chemotherapy. In vitro testing on a number of artemisinin-derivatives showed that artesunate (AS) and dihydroartemisinin (DHA) at $40 \mu \mathrm{M}$ caused considerable damage to metacestodes in vitro. However, in vivo treatment in mice was ineffective. Again, combination therapies of ABZ with DHA and AS, respectively, were slightly more efficacous than $A B Z$ alone, but results closely missed statistical significance (Spicher et al., 2008b).

\section{(2) Studies on antiproliferative drugs}

There are a number of links between growth of cancer cells and Echinococcus and other parasites (reviewed in Klinkert \& Heussler, 2006), namely their proliferative capacity, the potential to modulate the immune response, the secretion of proteolytic enzymes in order to reach their target sites or organs, and the capacitiy of metastasis formation. Echinococcus multilocularis metacestodes behave like malignant tumours, and there is an association between the uncontrolled proliferation and growth and the overexpression in metacestodes of a family of proteins named 14-3-3 (Siles-Lucas et al., 1998, 2001). 14-3-3 proteins are found in all eukaryotic cells and participate in protein kinase signalling pathways. They function as phosphoserine/phosphothreonine-binding modules and have an effect on phosphorylationdependent events such as DNA-damage checkpoints and prevention of apoptosis (reviewed in Siles-Lucas \& Gottstein, 2003). Some 14-3-3 proteins have been found to be aberrantly expressed in tumour cells, being either proor antitumorigenic. In fact, when Echinococcus 14-3-3 sequences were aligned with other 14-3-3 isoforms of other organisms, those overexpressed in metacestodes were grouped with the tumour-growth-related zeta- isoforms (Siles-Lucas et al., 2001). This indicates that antitumour agents interacting with 14-3-3-triggered pathways could have the potential to interfere in growth of Echinococcus metacestodes.

Doxorubicin, or hydroxyldaunorubicin, is a DNAinteracting drug widely used in chemotherapy, and is commonly used in the treatment of a wide range of cancers. The parasiticidal properties of doxorubicin against the metacestode of E. multilocularis were investigated after binding of that drug to polyisohexylcyanoacrylate nanoparticles, a colloidal biodegradable drug carrier. A reduction of the hepatic parasite development and a reduced viability of the metacestode were observed in mice injected with $5 \mathrm{mg} / \mathrm{kg}$ body weight, but $7.5 \mathrm{mg} / \mathrm{kg}$ body weight did not appear to be more efficient. Free doxorubicin or unbound nanoparticles had no antiparasitic activity (Liance et al., 1993).

Another class of antitumour agents with proven antiparasitic activities are isoflavonoids. Isoflavonoids are substances formed by plant tissue in response to physiological stimuli such as infectious agents, with reported anti-oxidant, antibacterial, antiviral and antifungal activity (Dakora \& Phillips, 1996). They are composed of a characteristic 15-carbon backbone ring structure connected by a heterocyclic pyrane (3-C) bridge (C6-C3-C6) (Reynaud et al., 2005), with the two aromatic rings generally containing a number of phenolic hydroxyl groups. Genistein, a major component of soya, is the most prominent isoflavonoid, and inhibits growth and metastasis of a number of cancer cell lines (breast, prostate, skin, colon). Genistein also stimulates the synthesis of transforming growth factor- $\beta$ (TGF- $\beta$ ), which itself inhibits cancer cell proliferation (Messina, 1999). Besides other targets, genistein acts on a number of signalling pathways, by functioning as a kinase inhibitor (tyrosine kinase, mitogen activated protein (MAP) kinase, ribosomal S6 kinase). Our own studies showed that genistein was highly effective against E. multilocularis metacestodes in vitro (Naguleswaran et al., 2006). However, genistein has a disadvantage, in that it also exerts oestrogenic effects by binding to oestrogen receptor- $\beta$ (Pike et al., 1999), and this renders genistein unfavourable for long-term treatment applications. Binding to the oestrogen receptor- $\beta$ has been proven to take place through the hydroxyl-group associated with the B-ring of the molecule. We have therefore tested a number of isoflavonoids in vitro, which do not carry this hydroxylgroup and therefore do not meet the steric requirements to bind to the oestrogen receptor- $\beta$. One of these compounds, Rm6423, exhibits pronounced antiparasitic activity against E. multilocularis metacestodes, as well as against E. granulosus metacestodes and protoscoleces (Naguleswaran et al., 2006). Further, examination of culture medium revealed increased leakage of parasite proteins into the medium during treatment, and zymography demonstrated a loss in the activity of metalloproteases. The molecular basis of the efficacy of genistein and its derivative Rm6423 have not been elucidated, but these compounds could interfere in signalling, for instance through inhibiting the tyrosine kinase activity associated with, for example, the 
epidermal growth factor receptor identified in E. multilocularis (Spiliotis et al., 2006).

2-Methoxyestradiol (2-ME), an endogenous metabolite of oestrogen with both anti-angiogenic and antitumour effects (reviewed in Schumacher \& Neuhaus, 2001), was shown to downregulate the protumorigenic 14-3-3- $\zeta$-isoform in a number of cancer cell types (Kumar et al., 2003), an isoform also overexpressed in Echinococcus metacestodes (SilesLucas \& Gottstein, 2003). Application of 2-ME $(2-10 \mu \mathrm{M})$ to E. multilocularis metacestodes in vitro caused severe damage and downscaled 14-3-3 transcription levels. In vivo however, 2-ME had no significant effects, although a combination therapy comprised of $\mathrm{ABZ}$ and 2-ME produced slightly better results than ABZ alone (Spicher et al., 2008a). The mechanism of action of 2-ME in cancer cells has been attributed to interference in microtubule stability and dysregulation of hypoxia-inducible factor (Attalla et al., 1996; Klauber et al., 1997; Mabjeesh et al., 2003), inducing cancer cells to undergo apoptosis via extrinsic and intrinsic pathways. It is not known how 2-ME exerts its effects on Echinococcus.

NTZ, previously introduced as an anti-infective drug, also inhibits the proliferation of colon cancer cells in vitro, probably by interfering with glutathioneS-transferase (GST) class $\pi$, an isoform overexpressed in many proliferating cells (Müller et al., 2008b). In E. granulosus and E. multilocularis, the only GSTs characterized so far have some sequence homologies to the mammalian class $\mu$ (Liebau et al., 1996; Fernandez et al., 2000). The catalytic properties of recombinant GST of E. multilocularis had, however, higher similarities to mammalian classes $\alpha$ and $\pi$, with, especially, a high conjugating activity on ethacrynic acid, an anticancer drug (Liebau et al., 1996). In principle, GSTs may have two opposite effects on drugs, namely by inactivating drugs or by activating ineffective pro-drugs. The latter effects have been employed as an anticancer drug strategy (Rooseboom et al., 2004) and may be further developed as an anti-Echinococcus strategy.

Cyclosporin A (CA) is an inhibitor of the protein phosphatase calcineurin and acts as an antiproliferative for lymphocytes, employed mainly as an immunosuppressant after organ transplantation (Ozbay et al., 2007). CA also exhibits anti-echinococcal activities in mice. While administration of CA in five consecutive daily doses, beginning 2 days prior to infection with E. granulosus protsocoleces, resulted in significant reduction in cyst numbers and cyst masses measured at 20 weeks post-infection, no changes in cyst mass and numbers were noted when the drug was administered 18 weeks post-infection. Ultrastructural examination of the germinal membrane and laminated layer of late-treated E. granulosus revealed abnormalities in all cysts studied, whereas control and earlytreated hydatids were normal (Hurd et al., 1993). In contrast to E. granulosus, CA did not have any antiparasitic activity against E. multilocularis infection in mice, and its immunosuppressive activity was shown to be more effective than its parasitostatic effect (Liance et al., 1992). Potential targets for CA in Echinococcus are unknown.
(3) The Echinococcus signalling machinery as a novel drug target

More recently, the excellent work of Brehm et al. has shed light on a number of developmental factors that E. multilocularis metacestodes share with other metazoans (for a review refer to Brehm et al., 2006). These include signalling systems that employ receptor tyrosine kinases of the epidermal growth factor (EGF) (Spiliotis et al., 2003, 2006), the insulin/insulin-like growth factor (Ins/IGF)receptor families (Konrad et al., 2003), and the surface serine/threonine kinases of the closely related transforming growth factor- $\beta$ (TGF- $\beta$ ) and bone morphogenetic protein (BMP)-receptor families (Zavala-Gongora et al., 2006). A cytokine that has significant homologies to mammalian EGF has been shown to be tenfold upregulated in E. multilocularis metacestodes cultured under conditions that promote growth and differentiation (Spiliotis et al., 2003). EmSkip, a novel member of the SNW/SKIP family of transcriptional co-regulators was found to be expressed in the Echinococcus metacestodes and protoscoleces during an infection of the intermediate host (Gelmedin et al., 2005). EmSkip interacts with EmSmadA and EmSmadB, two TGF- $\beta$ /BMP signal transducers of E. multilocularis (Zavala-Gongora et al., 2003), indicating a role of this protein in TGF- $\beta$ signalling processes in the parasite. In addition, downstream signalling elements of the MAP kinase cascade have been identified and characterized (Spiliotis \& Brehm, 2004; Spiliotis et al., 2005, 2006). The Echinococcus MAP kinase cascade factors share similarities, but also have differences, compared to their mammalian counterparts. The differences would represent prime candidate targets for the development of novel anthelminthic drugs. For instance, analysis of receptor activation has shown that the E. multilocularis insulin receptor EmIR interacts readily with insulin from the host. Moreover, TGF- $\beta$ receptor EmTR1, and possibly also the EGF-receptor EmER, interact with their corresponding host ligands (reviewed in Brehm et al., 2006). Thus, parasite and host have evolved means of communication that would largely influence the developmental biology of both parasite and host. These receptor-ligand systems certainly play a central role in host-parasite interaction processes, and thus represent interesting drug targets (Brehm et al., 2006). Cancer research has generated an enormous number of compounds that interfere in the functional activities of homologous receptors or respective downstream kinases (for review see Sioud \& Leirdal, 2007), and the challenge will be to identify those drugs, or respective derivatives, that inhibit these receptors, or the corresponding downstream enzymes, in a parasitespecific manner.

\section{(4) In silico approaches}

Mathis et al. (2005) have been the first to exploit the current genomic sequence information to define a drug target in Echinococcus in silico, and subsequently confirmed their hypothesis experimentally. In bacteria, the ribosomes are important antibiotic targets, and macrolides such as erythromycin and clarithromycin are agents that bind to the nascent peptide exit tunnel near 
the peptidyltransferase centre of large subunit rRNA (Rodriguez-Fonseca et al., 1995). Higher eukaryotes carry a guanine at position 2058 of both cytoplasmic and mitochondrial rRNAs, and this modification at this position has been demonstrated to confer the resistance of eukaryotic cells to macrolide antibiotics. In contrast, the mitochondrial rRNA of E. multilocularis carries an adenine at sequence position 2058, which would be predictive for susceptibility (Sander et al., 1997), while the nucleus-encoded rRNA is characterized by a guanine at 2058 (Mathis et al., 2005). Upon in vitro culture of E. multilocularis metacestodes with clarithromycin, parasites, as expected, exhibited severely impaired growth characteristics, presented morphologically altered mitochondria and displayed a lack of microtriches, all in a dose-dependent manner. Adult worms were also severely affected, lost their motility and displayed morphological alterations such as shortening and constriction of proglottids and increased vacuolization. This study (Mathis et al., 2005) is the first in Echinococcus to encourage the use of sequence-based in silico approaches for the exploitation of drugs, the mode of action of which is well studied at the molecular level and the corresponding target is precisely defined. However, a prerequisite for this is the availability of more comprehensive Echinococcus genome sequence information. In 2008, shotgun sequencing of the E. multilocularis genome (c. $270 \mathrm{MB}$ ) was completed (http://www.sanger.ac.uk/Projects/Echinococcus/).

This opens the door for the identification of drug targets by affinity chromatography followed by mass spectrometry (MS)-based sequencing and for reverse genetics by overexpressing or silencing genes of interest. Transient transfections of primary cells of E. multilocularis have already been performed (Spiliotis et al., 2008).

\section{Concluding remarks}

As outlined in this review, considerable efforts have been undertaken in order to improve the therapeutical options for the treatment of CE and AE. Benzimidazolebased treatments have considerably improved the prognosis of patients, but new developments are wanted since the current treatments are only parasitostatic and have numerous side-effects. Parasitocidal compounds in vivo have not been identified to date, but drugs with different modes of action, such as NTZ, AMB and oestradiol- and artemisinin-derivatives, having shown promising results in preclinical studies, may be tested in combination with ABZ or related benzimidazoles in order to develop a suitable parasiticidal therapy. So far, academic institutions provide a scientific basis for novel treatment options, but financial constraints constantly limit the further development of promising therapies. Therefore, considerably more input is needed by the pharmaceutical industry and governmental agencies, in order to provide solutions for these neglected diseases. Clearly, a medium- to high-throughput metacestode screening system, allowing preliminary in vitro assessments of novel drug classes and respective conclusions on structure-activity relationships, needs to be developed. Besides traditional screening methods, genomic approaches, focused on the discovery of the receptor-ligand interactions and associated signalling pathways that influence the parasite-host interactions, will provide new opportunities and promising targets for follow-up studies on novel therapeutical options.

\section{Acknowledgements}

The authors want to acknowledge the financial support by the Foundation der Schweizerischen Mobiliar Versicherungen, the Swiss Life Foundation, the Novartis Research Foundation, and the Swiss National Science Foundation (31-111780). J.M. is recipient of a Novartis Research Fellowship. We also thank Bruno Gottstein, Britta Stadelmann and Norbert Müller for helpful discussions and support.

\section{References}

Ali-Khan, Z., Siboo, R., Gomersall, M. \& Faucher, M. (1983) Cystolytic events and the possible role of germinal cells in metastasis in chronic alveolar hydatidosis. Annals of Tropical Medicine and Parasitology 77, 497-512.

Ammann, R. \& Eckert, J. (1995) Clinical diagnosis and treatment of echinococcosis in humans. pp. 411-430 in Thompson, R.C.A. \& Lymbery, A.J. (Eds) Echinococcosis and hydatid disease. Wallingford, CAB International.

Attalla, H., Makela, T.P., Adlercreutz, H. \& Andersson, L.C. (1996) 2-Methoxy-estradiol arrests cells in mitosis without depolymerizing tubulin. Biochemical and Biophysical Research Communications 228, 467-473.

Bartholomot, G., Vuitton, D.A., Harraga, S., Shi, D.Z., Giraudoux, P., Barnish, G., Wang, Y.H., MacPherson, C.N. \& Craig, P.S. (2002) Combined ultrasound and serologic screening for hepatic alveolar echinococcosis in central China. American Journal for Tropical Medicine and Hygiene 66, 23-29.

Blanton, R.E., Wachira, T.M., Zeyhle, E.E., Njoroge, E.M., Magambo, J.K. \& Schantz, P.M. (1998) Oxfendazole treatment for cystic hydatid disease in naturally infected animals. Antimicrobial Agents and Chemotherapy 42, 601-605.

Blum, G., Perkhofer, S., Haas, H., Schrettl, M., Würzner, R., Dierich, M. \& Lass-Flörl, C. (2008) Potential basis for amphotericin B resistance in Aspergillus terreus. Antimicrobial Agents and Chemotherapy 52, 1353-1355.

Brehm, K. \& Spiliotis, M. (2008) Recent advances in the in vitro cultivation and genetic manipulation of Echinococcus multilocularis metacestodes and germinal cells. Experimental Parasitology 119, 506-515.

Brehm, K., Kronthaler, K., Jura, H. \& Frosch, M. (2000) Cloning and characterization of beta-tubulin genes from Echinococcus multilocularis. Molecular and Biochemical Parasitolology 107, 297-302.

Brehm, K., Spiliotis, M., Zavala-Gongora, R., Konrad, C. \& Frosch, M. (2006) The molecular mechanisms of larval cestode development: first steps into an unknown world. Parasitology International 55, S15-S21.

Bresson-Hadni, S., Laplante, J.J., Lenys, D., Rohmer, P., Gottstein, B., Jacquier, P., Mercet, P., Meyer, J.P., Miguet, J.P. \& Vuitton, D.A. (1994) Sero-epidemiologic screening of Echinococcus multilocularis infection in 
a European area endemic for alveolar echinococcosis. American Journal of Tropical Medicine and Hygiene 51, 837-846.

Brunetti, E., Troia, G., Garlaschelli, A.L., Gulizia, R. \& Filice, C. (2004) Twenty years of percutaneous treatments for cystic echinococcosis: a preliminary assessment of their use and safety. Parassitologia 46, 367-370.

Casado, N., Rodriguez-Caabeiro, F., Jiménez, A., Criado, A. \& de Armas, C. (1989) In vitro effects of levamisole and ivermectin against Echinococcus granulosus protoscoleces. International Journal of Parasitology 19, 945-947.

Casado, N., Urrea-Paris, M.A., Moreno, M.J. \& Rodriguez-Caabeiro, F. (2001) Combined praziquantel and albendazole chemoprophylaxis in experimental hydatidosis. Parasitology Research 87, 787-789.

Chai, J., Menghebat, Wei, J., Deyu, S., Bin, L., Jincao, S., Chen, F., Xiong, L., Yiding, M., Xiuling, W., Dolikun, Guliber, Yanchun, W., Fanghua, G. \& Shuhua, X. (2004) Observations on clinical efficacy of albendazole emulsion in 264 cases of hepatic cystic echinococcosis. Parasitology International 53, 3-10.

Cobo, F., Yarnoz, C., Sesma, B., Fraile, P., Aizcorbe, M., Trujillo, R., Diaz-de-Liano, A. \& Ciga, M.A. (1998) Albendazole plus praziquantel versus albendazole alone as preoperative treatment in intra-abdominal hydatidosis caused by Echinococcus granulosus. Tropical Medicine and International Health 3, 462-466.

Dakora, F.D. \& Phillips, D.A. (1996) Diverse functions of isoflavonoids in legumes transcend anti-microbial definitions of phytoalexins. Physiological and Molecular Plant Pathology 49, 1-20.

Driscoll, M., Dean, E., Reilly, E., Bergholz, E. \& Chalfie, M. (1989) Genetic and molecular analysis of a Caenorhabditis elegans $\beta$-tubulin that conveys benzimidazole sensitivity. Journal of Cell Biology 109, 2993-3003.

Dueger, E.L., Moro, P.L. \& Gilman, R.H. (1999) Oxfendazole treatment of sheep with naturally acquired hydatid disease. Antimicrobial Agents and Chemotherapy 43, 2263-2267.

Eckert, J. \& Deplazes, P. (2004) Biological, epidemiological, and clinical aspects of echinococcosis, a zoonosis of increasing concern. Clinical Microbiology Reviews 17, 107-135.

Eckert, J., Thompson, R.C.A. \& Mehlhorn, H. (1983) Proliferation and metastases formation of larval Echinococcus multilocularis. I. Animal model, macroscopical and histological findings. Zeitschrift für Parasitenkunde 69, 737-748.

El-On, J. (2002) Benzimidazole treatment of cystic echinococcosis. Acta Tropica 85, 243-252.

Esposito, M., Mueller, N. \& Hemphill, A. (2007) Structure-activity relationships from in vitro efficacies of the thiazolide series against the intracellular apicomplexan protozoan Neospora caninum. International Journal for Parasitology 37, 183-190.

Fernandez, V., Chalar, C., Martinez, C., Musto, H., Zaha, A. \& Fernandez, C. (2000) Echinococcus granulosus: molecular cloning and phylogenetic analysis of an inducible glutathione-S-transferase. Experimental Parasitology 96, 190-194.

Frayha, G.J., Bikhazi, K.J. \& Kachachi, T.A. (1981) Treatment of hydatid cysts (Echinococcus granulosus) by
Cetrimide. Transactions of the Royal Society of Tropical Medicine and Hygiene 75, 447-450.

Garcia-Llamazares, J.L., Alvarez-de-Felipe, A.I., RedondoCardena, P., Voces-Alonso, J.A. \& Prieto-Fernandez, J.G. (1997) In vivo inhibition of the regenerative capacity of hydatid material after treatment with netobimin. Parasitology Research 83, 105-108.

Gelmedin, V., Zavala-Gongora, R., Fernandez, C. \& Brehm, K. (2005) Echinococcus multilocularis: cloning and characterization of a member of the SNW/SKIP family of transcriptional coregulators. Experimental Parasitology 111, 115-120.

Gottstein, B. \& Hemphill, A. (1997) Immunopathology of echinococcosis. Chemical Immunology 66, 177-208.

Gottstein, B., Dai, W.J., Walker, M., Stettler, M., Müller, N. \& Hemphill, A. (2002) An intact laminated layer is important for the establishment of secondary Echinococcus multilocularis infection. Parasitology Research $88,822-828$.

Gottstein, B., Haag, K., Walker, M., Matsumoto, J., Mejri, N. \& Hemphill, A. (2006) Molecular survival strategies of Echinococcus multilocularis in the murine host. Parasitology International 55, S45-S49.

Hemphill, A., Stettler, M., Walker, M., Siles-Lucas, M., Fink, R. \& Gottstein, B. (2002) Culture of Echinococcus multilocularis metacestodes; an alternative to animal use. Trends in Parasitology 18, 445-449.

Hemphill, A., Müller, J. \& Esposito, M. (2006) Nitazoxanide, a broad-spectrum thiazolide anti-infective agent for the treatment of gastrointestinal infections. Expert Opinion in Pharmacotherapy 7, 953-964.

Hemphill, A., Müller, N. \& Müller, J. (2007) Structurefunction relationship of thiazolides, a novel class of anti-parasitic drugs, investigated in intracellular and extracellular protozoan parasites and larval-stage cestodes. Antiinfective Agents in Medical Chemistry 6, 273-282.

Henriquez, F., Ingram, P.R., Muench, S.P., Rice, D.W. \& Roberts, C.W. (2008) Molecular basis for the resistance of Acanthamoeba tubulins to all major classes of antitubulin compounds. Antimicrobial Agents and Chemotherapy 52, 1133-1135.

Horton, R.J. (1989) Chemotherapy of Echinococcus infection in man with albendazole. Transactions of the Royal Society of Tropical Medicine and Hygiene 83, 97-102.

Horton, R.J. (1997) Albendazole in the treatment of human cystic echinococcosis: 12 years of experience. Acta Tropica 64, 79-93.

Hurd, H., Mackenzie, K.S. \& Chappell, L.H. (1993) Anthelmintic effects of cyclosporin A on protoscoleces and secondary hydatid cysts of Echinococcus granulosus in the mouse. International Journal for Parasitology 23, 315-320.

Ingold, K., Bigler, P., Thormann, W., Cavaliero, T., Gottstein, B. \& Hemphill, A. (1999) Efficacies of albendazole sulfoxide and albendazole sulfone against in vivo-cultivated Echinococcus multilocularis metacestodes. Antimicrobial Agents and Chemotherapy 43, 1052-1061.

Jorgensen, P., an der Heiden, M., Kern, P., Schöneberg, I., Krause, G. \& Alpers, K. (2008) Underreporting of human alveolar echinococcosis, Germany. Emerging Infectious Diseases 14, 935-937. 
Katiyar, S.K., Gordon, V.R., Mclaughlin, G.L. \& Edlind, T.D. (1994) Antiprotozoal activities of benzimidazoles and correlations with $\beta$-tubulin sequence. Antimicrobial Agents and Chemotherapy 38, 2086-2090.

Kern, P. (2003) Echinococcus granulosus infection: clinical presentation, medical treatment and outcome. Langenbecks Archives of Surgery 388, 413-420.

Kern, P. (2006) Medical treatment of echinococcosis under the guidance of Good Clinical Practice (GCP/ICH). Parasitology International 55 (Suppl.), S273-S282.

Klauber, N., Parangi, S., Flynn, E., Hamel, E. \& D'Amato, R.J. (1997) Inhibition of angiogenesis and breast cancer in mice by the microtubule inhibitors 2-methoxyestradiol and taxol. Cancer Research 57, 81-86.

Klinkert, M.Q. \& Heussler, V. (2006) The use of anticancer drugs in antiparasitic chemotherapy. Mini Reviews in Medicinal Chemistry 6, 131-143.

Konrad, C., Kroner, A., Spiliotis, M., Zavala-Gongora, R. \& Brehm, K. (2003) Identification and molecular characterisation of a gene encoding a member of the insulin receptor family in Echinococcus multilocularis. International Journal for Parasitology 33, 301-312.

Kumar, A.P., Garcia, G.E., Orsborn, J., Levin, V.A. \& Slaga, T.J. (2003) 2-Methoxyestradiol interferes with $\mathrm{NfkB}$ transcriptional activity in primitive neuroectodermal brain tumours: implications for management. Carcinogenesis 24, 209-216.

Kwa, M.S.G., Veenstra, J.G., Van Dijk, M. \& Roos, M.H. (1995) $\beta$-tubulin genes from the parasite nematode Haemonchus contortus modulate drug resistance in Caenorhabditis elegans. Journal of Molecular Biology 246, 500-516.

Lacey, E. (1990) Mode of action of benzimidazoles. Parasitology Today 6, 112-116.

Lawton, P., Walchshofer, N. \& Sarciron, M.E. (2001) In vitro effects of isoprinosine and a dipeptide methyl ester on Echinococcus multilocularis protoscoleces. Journal of Helminthology 75, 251-257.

Liance, M., Bresson-Hadni, S., Vuitton, D.A., Lenys, D., Carbillet, J.P. \& Houin, R. (1992) Effects of cyclosporin A on the course of murine alveolar echinococcosis and on specific cellular and humoral immune responses against Echinococcus multilocularis. International Journal for Parasitology 22, 23-28.

Liance, M., Nemati, F., Bories, C. \& Couvreur, P. (1993) Experience with doxorubicin-bound polyisohexylcyanoacrylate nanoparticles on murine alveolar echinococcosis of the liver. International Journal of Parasitology 23, 427-429.

Liebau, E., Müller, V., Lucius, R., Walter, R.D. \& HenkleDührsen, K. (1996) Molecular cloning, expression and characterization of a recombinant glutathione-S-transferase from Echinococcus multilocularis. Molecular and Biochemical Parasitology 77, 49-56.

Mabjeesh, N.J., Escuin, D., LaVallee, T.M., Pribluda, V.S., Swartz, G.M., Johnson, M.S., Willard, M.T., Zhong, H., Simons, J.W. \& Giannakakou, P. (2003) 2-ME2 inhibits tumor growth and angiogenesis by disrupting microtubules and dysregulating HIF. Cancer Cell 3, 363-375.

Marchiondo, A.A., Ming, R., Andersen, F.L., Slusser, J.H. \& Conder, G.A. (1994) Enhanced larval cyst growth of Echinococcus multilocularis in praziquantel-treated jirds
(Meriones unguiculatus). American Journal of Tropical Medicine and Hygiene 50, 120-127.

Martinez, J., Perez-Serrano, J., Bernadina, W.E. \& Rodriguez-Caabeiro, F. (1999) Echinococcus granulosus: in vivo effects of ivermectin and praziquantel on hsp60 and hsp70 levels. Experimental Parasitology 93, 171-180.

Mathis, A., Wild, P., Boettger, E.C., Kapel, C.M.O. \& Deplazes, P. (2005) Mitochondrial ribosome as the target for the macrolide antibiotic clarithromycin in the helminth Echinococus multilocularis. Antimicrobial Agents and Chemotherapy 49, 3251-3255.

Matsumoto, J., Müller, N., Hemphill, A., Oku, Y., Kamiya, M. \& Gottstein, B. (2006) 14-3-3- and II/3-10-gene expression as molecular markers to address viability and growth activity of Echinococcus multilocularis metacestodes. Parasitology 132, 83-94.

McManus, D.P., Wenbao, Z., Jun, L. \& Bartley, P.B. (2003) Echinococcosis. Lancet 362, 1295-1304.

Mehlhorn, H., Eckert, J. \& Thompson, R.C.A. (1983) Proliferation and metastases formation of larval Echinococcus multilocularis II. Ultrastructural investigations. Zeitschrift für Parasitenkunde 69, 749-763.

Messina, M. (1999) Soy, soy phytoestrogens (isoflavones), and breast cancer. American Journal of Clinical Nutrition 70, 574-575.

Miyaji, S., Katakura, K., Matsufuji, S., Murakami, Y., Hayashi, S., Oku, Y., Okamoto, M. \& Kamiya, M. (1993) Failure of treatment with alpha-difluoromethylornithine against secondary multilocular echinococcosis in mice. Parasitology Research 79, 75-76.

Morris, D.L. \& Richards, K.S. (1992) Hydatid disease. Current medical and surgical management. Oxford, Butterworth-Heinemann.

Morris, D.L. \& Taylor, D.H. (1990) Echinococcus granulosus: development of resistance to albendazole in an animal model. Journal of Helminthology 64, 171-174.

Müller, J., Sterck, M., Hemphill, A. \& Müller, N. (2007a) Characterization of Giardia lamblia WB C6 clones resistant to nitazoxanide and to metronidazole. Journal of Antimicrobial Chemotherapy 60, 280-287.

Müller, J., Wastling, J., Sanderson, S., Müller, N. \& Hemphill, A. (2007b) A novel Giardia lamblia nitroreductase, GINR1, interacts with nitazoxanide and other thiazolides. Antimicrobial Agents and Chemotherapy 51, 1979-1986.

Müller, J., Naguleswaran, A., Müller, N. \& Hemphill, A. (2008a) Neospora caninum: functional inhibition of protein disulfide isomerase by the broad-spectrum anti-parasitic drug nitazoxanide and other thiazolides. Experimental Parasitology 118, 80-88.

Müller, J., Sidler, D., Nachbur, U., Wastling, J., Brunner, T. \& Hemphill, A. (2008b) Thiazolides inhibit growth and induce glutathione-S-transferase pi (GSTP1)-dependent cell death in human colon cancer cells. International Journal of Cancer 123, 1797-1806.

Naguleswaran, A., Spicher, M., Vonlaufen, N., OrtegaMora, L.M., Torgerson, P., Gottstein, B. \& Hemphill, A. (2006) In vitro metacestodicidal activities of genistein and other isoflavones against Echinococcus multilocularis and Echinococcus granulosus. Antimicrobial Agents and Chemotherapy 50, 3770-3778. 
Nakao, M., McManus, D.P., Schantz, P.M., Craig, P.S. \& Ito, A. (2007) A molecular phylogeny of the genus Echinococcus inferred from complete mitochondrial genomes. Parasitology 134, 713-722.

Ohbayashi, M., Rausch, R.L. \& Fay, F.H. (1971) On the ecology and distribution of Echinococcus spp. (Cestoda: Taeniidae), and characteristics of their development in the intermediate host. II. Comparative studies on the larval E. multilocularis Leuckart, 1863, in the intermediate host. Japanese Journal of Veterinary Research 19, 1-9.

Ozbay, A., Karamperis, N. \& Jørgensen, K.A. (2007) A review of the immunosuppressive activity of cyclosporine metabolites: new insights into an old issue. Current Clinical Pharmacology 2, 244-248.

Pawlowski, Z.S. (1997) Critical points in the clinical management of cystid echinococcosis: a revised review. pp. 119-135 in Anderson, F.L., Ouhelli, H. \& Kachani, M. (Eds) Compendium on cystic echinococcosis. Provo, Brigham Young University.

Pawlowski, Z.S., Eckert, J., Vuitton, D.A., Ammann, R.W. Kern, P., Craig, P.S., Dar, K.F., De Rosa, F., Filice, C., Gottstein, B., Grimm, F., MacPhearson, C.N.L., Sato, N., Todorov, T., Uchino, J., von Sinner, W. \& Wen, H. (2001) Echinococcosis in humans: clinical aspects, diagnosis and treatment. pp. 20-32 in Eckert, J., Gemmell, M.A., Meslin, F.X. \& Pawlowski, Z.S. (Eds) WHO/OIE manual on echinococcosis in humans and animals: a public health problem of global concern. Paris, World Organization for Animal Health and World Health Organization.

Pike, A.C., Brzozowski, A.M., Hubbard, R.E., Bonn, T., Thorsell, A.G., Engström, O., Ljunggren, J., Gustafsson, J.A. \& Carlquist, M. (1999) Structure of the ligand-binding domain of oestrogen receptor beta in the presence of a partial agonist and a full antagonist. EMBO Journal 18, 4608-4618.

Rausch, R.L. (1995) Life cycle patterns and geographic distribution of Echinococcus species. pp. 89-99 in Thompson, R.C.A. \& Lymbery, A.J. (Eds) Echinococcosis and hydatid disease. Wallingford, CAB International.

Rausch, R.L., Wilson, J.F., Schantz, P.M. \& McMahon, B.J. (1987) Spontaneous death of Echinococcus multilocularis: case diagnosised serologically (by Em2-Elisa) and clinical significance. American Journal of Tropical Medicine and Hygiene 36, 576-585.

Reuter, S., Jensen, B., Buttenschoen, K., Kratzer, W. \& Kern, P. (2000) Benzimidazoles in the treatment of alveolar echinococcosis. Journal of Antimicrobial Chemotherapy 46, 451-460.

Reuter, S., Merkle, M., Brehm, K., Kern, P. \& Manfras, B. (2003a) Effect of amphotericin B on larval growth of Echinococcus multilocularis. Antimicrobial Agents and Chemotherapy 47, 620-625.

Reuter, S., Buck, A., Grebe, O., Nüssle-Kügele, K., Kern, P. \& Manfras, B. (2003b) Salvage treatment with amphotericin B in progressive human alveolar echinococcosis. Antimicrobial Agents and Chemotherapy 47, 3586-3591.

Reuter, S., Buck, A., Manfras, B., Kratzer, W., Seitz, H.M., Darge, K., Reske, S.N. \& Kern, P. (2004) Structured treatment interuption in patients with alveolar echinococcosis. Hepatology 39, 509-517.

Reuter, S., Manfras, B., Merkle, M., Harter, G. \& Kern, P. (2006) In vitro activities of itraconazole, methiazole, and nitazoxanide versus Echinococcus multilocularis larvae. Antimicrobial Agents and Chemotherapy 50, 2966-2970.

Reynaud, J., Guilet, D., Terreux, R., Lussignol, M. \& Walchshofer, N. (2005) Isoflavonoids in non-leguminous families: an update. Natural Products Reports 22, 504-515.

Rodrigues, J.M., Bories, C., Emery, I., Fessi, H., Devissaguet, J.P. \& Liance, M. (1995) Development of an injectable formulation of albendazole and in vivo evaluation of its efficacy against Echinococcus metacestodoe. International Journal for Parasitology 25, 1437-1441.

Rodriguez-Fonseca, C., Amils, R. \& Garret, R.A. (1995) Fine structure of the peptidyl transferase centre on 23S-like rRNAs deduced from chemical probing of antibiotic ribosome complexes. Journal of Molecular Biology 27, 224-235.

Rogan, M.T. \& Richards, K.S. (1986) Echinococcus granulosus: in vivo effect of monensin on the tegument of the protoscolex. Parasitology 93, 347-355.

Rooseboom, M., Commandeur, J.N.M. \& Vermeulen, N.P.E. (2004) Enzyme-catalyzed activation of anticancer prodrugs. Pharmacological Reviews 56, 53-102.

Rubino, S., Fiori, P.L., Lubinu, G., Monaco, G. \& Cappucinelli, P. (1983) The cytoskeleton of hydatid cyst cultured cells and its sensitivity to inhibitors. European Journal of Cell Biology 30, 182-190.

Sander, P.T., Prammananan, T., Meier, A., Frischkorn, K. \& Bottger, E.C. (1997) The role of ribosomal RNAs in macrolide resistance. Molecular Microbiology 26, 469-480.

Sarciron, M.E., Walchshofer, N., Walbaum, S., Arsac, C., Descotes, J., Petavy, A.F. \& Paris, J. (1997) Increases in the effects of albendazole on Echinococcus multilocularis metacestodes by the dipeptide methyl ester (Phe-PheOMe). American Journal of Tropical Medicine and Hygiene 56, 226-230.

Satou, T., Koga, M., Matsuhashi, R., Koike, K., Tada, I. \& Nikaido, T. (2002) Assay of nematocidal activity of isoquinoline alkaloids using third-stage larvae of Strongyloides ratti and S. venezuelensis. Veterinary Parasitology 104, 131-138.

Schantz, P.M., Chai, J., Craig, P.S., Eckert, J., Jenkins, D.J., Macpherson, C.N.L. \& Thakur, A (1995) Epidemiology and control of hydatid disease. pp. 233-245 in Thompson, R.C.A. \& Lymbery, A.J. (Eds) Echinococcosis and hydatid disease. Wallingford, CAB International.

Schumacher, G. \& Neuhaus, P. (2001) The physiological estrogen metabolite 2-methoxyestradiol reduces tumor growth and induces apoptosis in human solid tumors. Journal of Cancer Research and Clinical Oncology 127, 405-410.

Siles-Lucas, M. \& Gottstein, B. (2003) The 14-3-3 protein: a key molecule in parasites as in other organisms. Trends in Parasitology 19, 575-581.

Siles-Lucas, M. \& Hemphill, A. (2002) Cestode parasites: application of in vivo and in vivo models for studies on the host-parasite relationship. Advances in Parasitology 51, 133-230.

Siles-Lucas, M., Felleisen, R.S., Hemphill, A., Wilson, W. \& Gottstein, B. (1998) Stage-specific expression of the 14-3-3 gene in Echinococcus multilocularis. Molecular and Biochemical Parasitolology 91, 281-293. 
Siles-Lucas, M., Nunes, C.P. \& Zaha, A. (2001) Comparative analysis of the 14-3-3 gene and its expression in Echinococcus granulosus and Echinococcus multilocularis metacestodes. Parasitology 122, 281-287.

Sioud, M. \& Leirdal, M. (2007) Druggable signaling proteins. Methods in Molecular Biology 361, 1-24.

Spicher, M., Naguleswaran, A., Ortega-Mora, L.M., Müller, J., Gottstein, B. \& Hemphill, A. (2008a) In vitro and in vivo effects of 2-methoxyestradiol, either alone or combined with albendazole, against Echinococcus metacestodes. Experimental Parasitology 119, 467-474.

Spicher, M., Roethlisberger, C., Lany, C., Stadelmann, B., Keiser, J., Ortega-Mora, L.M., Gottstein, B. \& Hemphill, A. (2008b) In vitro and in vivo treatments of Echinococcus protoscoleces and metacestodes with artemisinin and artemisinin derivatives. Antimicrobial Agents and Chemotherapy 52, 3447-3450.

Spiliotis, M. \& Brehm, K. (2004) Echinococcus multilocularis: identification and molecular characterization of a Ral-like small GTP-binding protein. Experimental Parasitology 107, 163-172.

Spiliotis, M., Kroner, A. \& Brehm, K. (2003) Identification, molecular characterization and expression of the gene encoding the epidermal growth factor receptor orthologue from the fox-tapeworm Echinococcus multilocularis. Gene 323, 57-65.

Spiliotis, M., Tappe, D., Sesterhenn, L. \& Brehm, K. (2004) Long-term in vitro cultivation of Echinococcus multilocularis metacestodes under axenic conditions. Parasitology Research 92, 430-432.

Spiliotis, M., Tappe, D., Bruckner, S., Mosch, H.U. \& Brehm, K. (2005) Molecular cloning and characterization of Ras- and Raf-homologues from the foxtapeworm Echinococcus multilocularis. Molecular and Biochemical Parasitology 139, 225-237.

Spiliotis, M., Konrad, C., Gelmedin, V., Tappe, D., Bruckner, S., Mosch, H.U. \& Brehm, K. (2006) Characterisation of EmMPK1, an ERK-like MAP kinase from Echinococcus multilocularis which is activated in response to human epidermal growth factor. International Journal for Parasitology 36, 1097-1112.

Spiliotis, M., Lechner, S., Tappe, D., Scheller, C., Krohne, G. \& Brehm, K. (2008) Transient transfection of Echinococcus multilocularis primary cells and complete in vitro regeneration of metacestode vesicles. International Journal for Parasitology 38, 1025-1039.

Stettler, M., Siles-Lucas, M., Sarciron, E., Lawton, P., Gottstein, B. \& Hemphill, A. (2001) Echinococcus multilocularis alkaline phosphatase as a marker for metacestode damage induced by in vivo drug treatment with albendazole sulfoxide and albendazole sulfone. Antimicrobial Agents and Chemotherapy 45, 2256-2262.

Stettler, M., Fink, R., Walker, M., Gottstein, B., Geary, T.G., Rossignol, J.F. \& Hemphill, A. (2003) In vivo parasiticidal effect of nitazoxanide against Echinococcus multilocularis metacestodes. Antimicrobial Agents and Chemotherapy 47, 467-474.

Stettler, M., Rossignol, J.F., Fink, R., Walker, M., Gottstein, B., Merli, M., Theurillat, R., Thormann, W., Dricot, E., Segers, R. \& Hemphill, A. (2004) Secondary and primary murine alveolar echinococcosis: combined albendazole/nitazoxanide chemotherapy exhibits profound anti-parasitic activity. International Journal for Parasitology 34, 615-624.

Stey, C. \& Jost, R. (1993) Rezidivierende, lebensbedroliche Anaphylaxie als Erstmanifestation eines Echinococcus cysticus (granulosus) der Leber. Schweizerische Medizinische Wochenzeitschrift 123, 1445-1450.

Taylor, D.H., Richards, K.S. \& Morris, D.L. (1989) Rapid recovery of Echinococcus granulosus following 'successful' albendazole therapy in a gerbil model. Journal of Helminthology 63, 349-352.

Thompson, R.C.A. (1986) Biology and systematics of Echinococcus. pp. 5-17 in Thompson, R.C.A. (Ed.) The biology of Echinococcus and hydatid disease. London, Allen \& Unwin.

Torgerson, P.R. (2003) Economic effects of echinococcosis. Acta Tropica 85, 113-118.

Urrea-Paris, M.A., Moreno, M.J., Casado, N. \& RodriguezCaabeiro, F. (1999) Echinococcus granulosus: praziquantel treatment against the metacestode stage. Parasitology Research 85, 999-1006.

Urrea-Paris, M.A., Casado, N., Moreno, M.J. \& RodriguezCaabeiro, F. (2001) Chemoprophylactic praziquantel treatment in experimental hydatidosis. Parasitology Research 87, 510-512.

Varcasia, A., Garippa, G., Pipia, A.P., Scala, A., Brianti, E., Giannetto, S., Battelli, G., Poglayen, G. \& Micagni, G. (2008) Cystic echinococcosis in equids in Italy. Parasitology Research 102, 815-818.

Vuitton, D.A., Zhang, S.L., Yang, Y., Godot, V., Beurton, I., Mantion, G. \& Bresson-Hadni, S. (2006) Survival strategy of Echinococcus multilocularis in the human host. Parasite International 55, S51-S55.

Walchshofer, N., Delabre-Defayolle, I., Paris, J. \& Petavy, A.F. (1990) In vivo morphological damage induced by a new benzimidazole pro-drug in Echinococcus multilocularis metacestodes. Journal of Pharmacological Science 79, 606-608.

Walker, M., Baz, A., Dematteis, S., Stettler, M., Gottstein, B., Schaller, J. \& Hemphill, A. (2004a) Isolation and characterization of a secretory component of Echinococcus multilocularis metacestodes potentially involved in modulating the host-parasite interface. Infection and Immunity 72, 527-536.

Walker, M., Rossignol, J.F., Torgerson, P. \& Hemphill, A. (2004b) In vivo effects of nitazoxanide on Echinococcus granulosus protoscoleces and metacestodes. Journal of Antimicrobial Chemotherapy 54, 609-616.

Wangoo, A., Ganguly, N.K. \& Mahajan, R.C. (1987) In vivo efficacy of mebendazole in containment of larval cyst mass in early stages of hydatid disease due to Echinococcus granulosus. Transactions of the Royal Society of Tropical Medicine and Hygiene 81, 965-966.

Wen, H., New, R.R., Muhmut, M., Wang, J.H., Wang, Y.H., Zhang, J.H., Shao, Y.M. \& Craig, P.S. (1996) Pharmacology and efficacy of liposome-entrapped albendazole in experimental secondary alveolar echinococcosis and effect of co-administration with cimetidine. Parasitology 113, 111-121.

Xiao, S., Feng, J. \& Yao, M. (1995) Effect of anti-hydatid drugs on carbohydrate metabolism of metacestode of 
Echinococcus granulosus. Chinese Medical Journal 108, 682-688.

Zavala-Gongora, R., Kroner, A., Wittek, B., Knaus, P. \& Brehm, K. (2003) Identification and characterisation of two distinct Smad proteins from the fox-tapeworm Echinococcus multilocularis. International Journal for Parasitology 33, 1665-1677.

Zavala-Gongora, R., Kroner, A., Bernthaler, P., Knaus, P. \& Brehm, K. (2006) A member of the transforming growth factor-beta receptor family from Echinococcus multilocularis is activated by human bone morphogenetic protein 2. Molecular and Biochemical Parasitology 146, 265-271.

(Accepted 23 January 2009)

First Published Online 19 March 2009 (C) 2009 Cambridge University Press 